JOINT REGULATION OF CONSUMER COMPLAINTS IN LEGAL

SERVICES: A COMPARATIVE STUDY [1]

\title{
MARY SENEVIRATNE
}

Centre for Legal Research, Nottingham Trent University, U.K.

\section{Introduction}

Where consumers have complaints about the quality of legal services in the United Kingdom, the mechanism for dealing with them has been described as a system of “joint regulation” (Barnes 1994: 61). In essence, such a model provides for independent supervision of the self-regulatory processes operated by the relevant professional bodies. It has also been referred to as a "Super-Escalated Complaints Environment” (Customer Management Consultancy Ltd 1998), with the professional bodies as the first tier for handling consumer complaints, and an ombudsman, or ombudsman-like adjudicator process, as the second tier. This model, involving public statutory oversight of private self-regulatory redress systems, can work well. It has many advantages, not least being the fact that most of the cost of the scheme is borne by the professional bodies. It does, however, depend on the first tier, the professional bodies’ own arrangements, being effective. 
Such a system has existed in England, Wales and Scotland since 1991, with the establishment, by statute (Courts and Legal Services Act 1990), of a Legal Services Ombudsman for England and Wales, and for Scotland, the Scottish Legal Services Ombudsman (Law Reform (Miscellaneous Provisions)(Scotland) Act 1990). In Northern Ireland, there is no statutory ombudsman, and the independent element to the self-regulatory system is provided by the Lay Observer, a system similar to those operating in England and Wales and Scotland before 1991. In the Republic of Ireland, an Independent Adjudicator was appointed in 1997 to investigate how the Law Society handles complaints from members of the public against solicitors.

All these schemes provide some supervision of the self-regulatory mechanisms of the legal profession. They do so, however, in different ways, and with different degrees of independence. The Legal Services Ombudsman scheme for England and Wales has been the subject of research (James and Seneviratne 1995). That research concluded that that scheme was independent, accountable, fair, and operated efficiently and effectively within the powers of the legislation, and within its limited budget. However, it was felt that the Ombudsman had not been given sufficient powers in the Courts and Legal Services Act 1990, to perform an effective oversight function It also had to be acknowledged that there was little that the Ombudsman could do if the selfregulatory mechanisms of the professional bodies were not working effectively.

There has been no detailed similar evaluation of the work of the Scottish Legal Services Ombudsman, the Lay Observer in Northern Ireland, or the Independent Adjudicator in the Republic of Ireland [2]. A comparative study of these three schemes therefore seemed appropriate, in order to draw some conclusions about the suitability of these arrangements for dealing with consumer complaints. The purpose 
of the study was to evaluate the independent mechanisms in Scotland, Northern Ireland and the Irish Republic, and set them within the context of the self-regulatory mechanisms of the profession [3]. Each scheme was evaluated to discover the extent to which it met the requirements of independence, effectiveness, fairness, and public accountability. These are the "four key criteria" which must be met before the British and Irish Ombudsman Association [4] will accord public recognition to an ombudsman. Of course, not all the schemes use the term "ombudsman" in their title, but these criteria form a useful starting point for evaluation. In essence, the purpose of all the schemes is to ensure public confidence and client satisfaction in the legal profession. The evaluation is to assess the extent to which they do so.

\section{Complaint handling by the professions}

The legal professions in the three countries studied are much smaller than in England and Wales. In England and Wales, there are about 80,000 practising solicitors and over 12,000 practising barristers. In Scotland, there are 8,600 solicitors and between 300/350 advocates. Northern Ireland has a small number of practising solicitors: 1,645 in total, which comprise 975 practising partners and 670 assistant solicitors. There are less than 500 firms, almost half of which are sole practitioners; 96 per cent of the firms have five partners or less. The largest firm consists of 13 partners. In the Irish Republic, there are 7,000 solicitors, 5,200 of which have practising certificates. Most of the firms in Ireland are small; there are only four firms with 80 or more solicitors. 
Like other professions, the legal professions in the three countries studied operate largely by means of self-regulation within a statutory framework. As self-regulatory bodies, they deal with complaints about conduct and can impose disciplinary sanctions and refer misconduct cases to independent disciplinary tribunals. Most consumer complaints are not about issues of a disciplinary nature, but are concerned with the quality of service provided. Inadequate professional service complaints include excessive delay, failure to respond to calls, failure to follow instructions, rudeness, arrogance, and, in particular, the cost of services. The legal professions have traditionally concentrated upon misconduct complaints, but they now have mechanisms for dealing with consumer complaints about the quality of the service provided.

The legal professions in Scotland, Northern Ireland and the Irish Republic have not suffered the same crisis in complaint handling that has been experienced in England and Wales. There, towards the end of the 1990s, complaint handling in the legal profession reached a crisis point, mainly for the solicitors profession, where the number of complaints in 1998 was well over 30,000. The United Kingdom Government responded to this crisis by announcing its intention to take a more interventionist approach in this matter, by appointing a Complaints Commissioner, if these problems were not sorted out by the profession (See Seneviratne 2000). In response, the profession has made efforts to improve its complaints handling record, and the Law Society has made significant progress in this area over the past year (see Legal Services Ombudsman 2001: 5, 21-22).

In Scotland, the Law Society of Scotland has a statutory duty to investigate complaints about solicitors. Complaints are dealt with by the Client Relations Office 
of the Law Society, and have to be in writing, either by letter or a complaint form. If the complaint is about service, rather than conduct, there is an attempt at conciliation. If this fails, a formal investigation is undertaken, and the solicitor is asked for a response to the complaint. The Client Relations Office gathers the relevant information and agrees the heads of complaint. This information is then sent to a reporter, who gives an opinion on whether the complaint has been established, together with a recommendation for a remedy. These reporters may be legally qualified or lay, and they are recruited by the Law Society after open advertisement. All reporters are unpaid and their identity is not revealed, which is a cause for concern to both complainants and solicitors who are the subject of complaints. The reporters' opinions and recommendations are discussed by the clients relations committees, which meet monthly. These committees, which usually agree with the opinion of the reporters but not necessarily the recommended sanctions, make a recommendation to the Council of the Law Society, which makes the final decision. The awards that can be made against the solicitor are the restriction, refund or waiving of fees, compensation or both. The maximum award that can be made for compensation is $£ 1,000$, and the average award is $£ 250$. The Law Society can also order solicitors to rectify an error which is within the solicitors' powers to put right, at the solicitors' own expense.

In Northern Ireland, complaints against solicitors are dealt with by the Assistant Secretary of the Law Society and the Professional Conduct Committee. If the complaint is about inadequate professional services, the Assistant Secretary obtains the file and reports to the committee, sometimes with a recommendation. If the service complaint is made out, the committee can award a reduction or waiving of 
fees. There is no power to award compensation. If the poor service complaint is deemed serious enough, the committee can issue a reprimand, or refer it to the Disciplinary Tribunal.

In the Republic of Ireland, consumer complaints against solicitors are dealt with by the complaints section of the Law Society. Complaints have to be in writing, and the complaints section try to mediate or negotiate a settlement on an informal basis. A decision is reached about a complaint of inadequate professional service on the basis of the file, which they request from the solicitor. The sanctions that can be awarded are a refund of fees, or rectification of the problem at the solicitor's expense. There is no power to award compensation or damages. If the solicitor does not respond to the recommendation, the matter is referred to the Registrars Committee, which can issue a direction. This becomes binding within 21 days, and during this time, there can be an appeal to the High Court. If the solicitor refuses to accept the direction after 21 days, the matter becomes one of misconduct, and is then dealt with as a disciplinary matter.

\section{The oversight mechanisms}

In all jurisdictions, the primary responsibility for dealing with client complaints rests with the professional bodies themselves. If the complainant is not satisfied with the professional body's handling of the complaint, the matter can be referred to an independent oversight mechanism. 
The scheme in Scotland is similar to that in England and Wales. The office of the Scottish Legal Services Ombudsman was established in 1991, as a result of the Law Reform (Miscellaneous Provisions) (Scotland) Act 1990. This Act parallels the Act setting up the Legal Services Ombudsman in England and Wales, with some important differences. As in England and Wales, Scotland used to have a Lay Observer, an independent person empowered to examine any allegation from a member of the public concerning the Law Society of Scotland's treatment of a complaint against a solicitor. The Ombudsman's post has developed from this. The function of the Scottish Legal Services Ombudsman is to investigate the handling of complaints against legal practitioners. Dissatisfied clients must first take their complaints about legal practitioners to the relevant professional body. If they are dissatisfied with the handling of the complaint by that body, they can refer the matter to the Ombudsman. The professional bodies subject to the Scottish Legal Services Ombudsman's jurisdiction are: the Law Society of Scotland (which regulates solicitors); the Faculty of Advocates (which regulates advocates); and the Scottish Conveyancing \& Executory Services Board (which regulates qualified conveyancers and executory practitioners).

The Ombudsman is concerned that the investigation of the complaint by the professional body has been fair and thorough, that all the heads of the complaint have been properly addressed, and that appropriate action has been taken. There is no jurisdiction to investigate the merits of the decisions taken by the professional bodies, that is, there is no power to investigate the original complaint and come to a different conclusion. Thus, the Scottish Legal Services Ombudsman is performing an oversight role for the professional bodies' complaints systems. This is unlike other ombudsman 
schemes in the public and private sectors, where the function is to investigate the substance of the original complaint, usually after the complainant has not obtained satisfaction from the organisation's internal grievance mechanisms. It is also unlike the Legal Services Ombudsman scheme in England and Wales, where, although the primary role is the investigation of the handling of the complaint by the professional body, the original complaint may be investigated. It should be noted, however, that in the vast majority of cases, the Legal Services Ombudsman in England and Wales does not use the discretion to extend investigation to the original complaint (see James and Seneviratne 1995: 193). Moreover, the number of cases where this was done “declined dramatically” in 1999/2000, following a decision by the Legal Services Ombudsman to take a "more robust approach" to referring cases back to the professional bodies for reconsideration (see Legal Services Ombudsman 2000: 15).

In Northern Ireland independent oversight of the complaint handling process is provided by the Lay Observer. The Lay Observer is appointed by virtue of the Solicitor (Northern Ireland) Order 1976, as amended by the Solicitors (Amendment) (Northern Ireland) Order 1989. The Lay Observer's remit is limited to the monitoring of complaints made to the Law Society of Northern Ireland about the conduct of solicitors. The Lay Observer is concerned with the manner in which the complaints are dealt with by the Law Society, particularly that the Law Society has acted impartially. Again, there is no power to investigate the merits of the original complaint. The remit is limited to solicitors, and there is thus no independent oversight of the complaint handling procedures of barristers in Northern Ireland. 
The Independent Adjudicator of the Law Society in the Republic of Ireland was established in October 1997, although the legal basis for the scheme is found in the Solicitors (Amendment) Act 1994. The primary function of the Independent Adjudicator is to adjudicate on the manner in which the Law Society has dealt with a formal complaint against a solicitor. The remit involves the general review of the procedures of the Law Society in relation to the handling of complaints, and making recommendations as necessary in order to improve the complaints process. The Adjudicator cannot investigate the merits of the original complaint, nor does the remit extend to complaints against barristers.

\section{The schemes in practice}

In Scotland, the Scottish Legal Services Ombudsman's function is to investigate the handling of complaints against legal practitioners, and the concern is whether the investigation by the professional body was fair and thorough and whether appropriate action was taken. The Ombudsman also determines whether a professional body acted fairly and reasonably in refusing to investigate a complaint about a practitioner. Indeed, about 40 per cent of complaints to the Ombudsman about the Law Society concern the refusal of the Law Society to investigate a complaint.

The intervention of the Scottish Legal Services Ombudsman is triggered by a complainant. When the professional body disposes of a case, dissatisfied complainants may refer it to the Ombudsman within six months of disposal. When a complaint is received, the Ombudsman identifies, as far as possible, what the 
problems were in terms of the professional body's handling of the complaint. The complainant is informed that the complaint has been accepted and advised of the likely timescale for production of the opinion. At the time of research, this was about 12 months. The present Ombudsman, who took the post on 1 July 2000, was of the opinion that this timescale was unacceptable. Within five months of her appointment, she reduced the turnaround time to six months, with the aim of its being between three and 13 weeks, depending upon the complexity of the case (see Justice 1 Committee 2001: col. 2531).

The practitioner is informed that a complaint against him or her has been referred to the Ombudsman. The Ombudsman requests the file from the professional body. Until recently, the Ombudsman used to send a copy of the complainant's letter to the professional body. The present Ombudsman was concerned about this practice and was also aware that some complainants were uncomfortable about it. Copy letters are now no longer sent. Instead, the Ombudsman writes to the professional body with a list of the concerns expressed by the complainant (see Scottish Legal Services Ombudsman 2001: 39). The professional body forwards the file to the Ombudsman, and a caseworker reads it and prepares an opinion. Files are dealt with in chronological order, being dated from the time the Ombudsman accepts the complaint. The draft opinion is sent to the Ombudsman, who reviews it, makes any amendments, and finalises it. The opinion is sent to the professional body, the complainant and the solicitor.

The Scottish Legal Services Ombudsman has a small workload compared with the Legal Services Ombudsman in England and Wales, although the proportion of 
complaints to the size of the population is similar. In 1999/2000, the Legal Services Ombudsman in England and Wales received over 3,000 new inquiries and conducted over 1,500 investigations (see Legal Services Ombudsman 2000: 7, 13). In 1999, the Scottish Legal Services Ombudsman issued opinions in 100 cases (Scottish Legal Services Ombudsman 2000: 5). From April 2000 to March 2001, the office received 104 complaints which would result in a formal Ombudsman opinion. The volume of complaints has fluctuated over the years, and there does not appear to be a definite trend. Over the past five years there has been an average of 120 new complaints a year which were within the Ombudsman's remit to investigate. There does not appear to have been a significant increase in the number of inquiries received by the office over the years, with last year's figure being 370 (Scottish Legal Services Ombudsman 2001: 4, 11). The vast majority of cases concern solicitors, with only a handful (between one and four each year in the past five years) of cases concerning advocates. There have been no cases involving qualified conveyancers or executory practitioners.

Most of the complaints which are not accepted for investigation by the Ombudsman are where the complainant has not taken the complaint to one of the professional bodies. Others are excluded because they are outside the six-month deadline, or because the Ombudsman has already prepared an opinion on the same matter. Some complaints refer to aspects of the legal system which are not within the Ombudsman's remit, for example, legal aid, sheriffs and procurators fiscal. If the Ombudsman's office is not able to deal with a complaint, there is an attempt to provide information about the person or organisation which may be able to resolve the problem (Scottish Legal Services Ombudsman 2001: 11-12). 
In Northern Ireland, the Lay Observer has two functions. He has to report on the nature of complaints being made to the Law Society and the manner in which they are dealt with. He also has to examine allegations from the public about the way complaints have been dealt with by the Law Society. The majority of his time is spent on the first function, which he does by examining the complaints files of the Law Society, without a referral by a complainant. Unlike in England and Wales and Scotland, the Lay Observer has access to all the files of the Law Society. He conducts his oversight responsibility by requesting a list of all the complaints files. From this, he selects, usually at random, the files he wants to examine. In 1999-2000, he reviewed about 35 per cent of the total complaints included in the computer system of the Law Society. From this review, he assesses whether any improvements need to be made to the system, and he makes recommendations as appropriate. Individual complaints take up very little of his time, as he receives only a small number of complaints directly from members of the public. In 1999-2000, there were 20 such complaints, and in the previous year, it was 28, the number each year for the past five years ranging from 25-32 (Lay Observer 2001: 24). The few complaints he does receive are dealt with informally, and it appears that he tries, in the main, to conciliate.

In the Irish Republic, the Independent Adjudicator's function is to respond to allegations about the manner in which the Law Society has dealt with a complaint against a solicitor. In 1998-99, he reviewed 56 cases at the invitation of complainants, a similar number to the previous year, when he examined 59 cases (Independent Adjudicator of the Law Society 1999: 9). In these cases, he doe not investigate the original complaint, his role being limited to ensuring that the complaint has been dealt 
with properly. The Adjudicator is also charged with generally reviewing the complaint handling procedures of the Law Society, and making recommendations for improving these as appropriate. The way he carries out his review is similar to the method operated by the Lay Observer. He randomly selects files from the Law Society's complaints files, in order to perform an overview the way the complaints section is operating. This is normally done on a six-monthly basis, and he reviews about 5 per cent of all the files.

\section{Independence and accountability}

In order to inspire public confidence, these oversight schemes must be independent and accountable. In Scotland, the Scottish Legal Services Ombudsman was appointed by, and was accountable to, the Secretary of State for Scotland. Since devolution, the Ombudsman is appointed by Scottish Ministers. Appointments are made after public advertisement and open competition, in consultation with the Lord President of the Court of Session. The main mechanism for implementing accountability is through the annual report, which since devolution, is laid before the Scottish Parliament. The Scottish Legal Services Ombudsman is a part-time appointment, the Ombudsman being employed for four days each week, supported by two full-time complaints officers, and a part-time secretary. The office is funded by the Scottish Executive, operating within a small budget. In 1999-2000, the total cost was $£ 156,000$. The budget for the forthcoming year has been set at $£ 185,000$, to reflect the increased cost of developing a new website and increased office rent (Scottish Legal Services Ombudsman 2001: 16). The office has links with the Scottish Executive Justice 
Department concerning the practical management of the office, but the Scottish Executive does not intervene in the way the office is run, nor with handling of individual complaints.

In Northern Ireland, the Lay Observer is appointed by the Head of the Department of Finance, after consultation with the Lord Chief Justice. Appointments are made on a competitive basis, following public service guidelines. The office is funded by the Office of Law Reform [5]. The Lay Observer is paid a salary, but has no permanent office, no office allocation, and no formal budget for staff. It is a government funded post, and he uses the premises and secretarial support provided by the Office of Law Reform, on an informal basis. The Department of Finance meets his expenses. It is a part-time appointment, the commitment of the post-holder averaging about one and a half days each week

In the Republic of Ireland, the impetus for setting up the Independent Adjudicator scheme came from the government, driven by the press and complainants. However, the Act establishing the office allowed for the appointment to be made by the Law Society, and the post is funded by the Law Society. It is a part-time post, the average workload accounting for about two and a half days each week. The Adjudicator is formally accountable to the Law Society, presenting his annual report to the President of the Law Society of Ireland. This does raise questions about the independence of the office. The Adjudicator admits that this does cause problems, but he has no doubts about his independence, and believes he has allayed the doubts of the press on this score. He is "fully satisfied" that he has "both the resources and independence" to carry out his responsibilities (Independent Adjudicator of the Law Society 1999: 5). 
However, he appreciates that there is a problem of perception for complainants about his independence, particularly where there is not a positive result for them.

In none of the schemes (or in England and Wales) can the office holder be legally qualified. This ensures that a lay view is incorporated into the complaint handling system. The office holders in the three schemes have a variety of backgrounds. The present Scottish Legal Services Ombudsman has worked in the public and private sectors, including consultancy work on complaint systems; the previous one had been a merchant banker. The present Lay Observer has worked in the oil industry and in academia. The Independent Adjudicator is a retired banker. As in many ombudsman/adjudicator schemes, the office holders are allowed considerable autonomy when in post. Because of this, the focus and perspective of the schemes depend to a large extent on the personal qualities of the individuals holding the posts at any one time. This is particularly evident in Northern Ireland, where the present Lay Observer is much more proactive than the previous one, a factor that is reflected in the style of the annual reports. The previous office holder produced fairly short, factual reports, normally expressing satisfaction with the complaint handling functions of the Law Society (see Lay Observer 1998). The annual reports of the present Lay Observer are thematic [6], contain a number of recommendations to the Law Society, make comments on the statistical tables, and discuss issues in relation to the environment in which solicitors practice in Northern Ireland. The Scottish Legal Services Ombudsman is very consumer-focussed, considering that to be effective she must be able to see the problem from the consumer's viewpoint. 
All the office holders are clear that they are not "consumer champions”, as such an approach would impact upon the impartiality of the office. The Independent Adjudicator has noted that he is "committed to the principal of fairness and balance to all parties” (Independent Adjudicator of the Law Society 1999: 5). However, there is a sense that in order to be fair, it is sometimes necessary to give a little extra for complainants for example, in terms of access, explanation or empowerment. The Scottish Legal Services Ombudsman considers that in order to be balanced, access and explanation need to be weighted toward the complainant. The Lay Observer has remarked that because of the imbalance of power, he is in fact championing the rights of consumers, and he has recommended that the Law Society should make its complaint handling procedures more complainant orientated (Lay Observer 2001: 10).

All the office holders are clearly independently minded and there can be no doubt about their personal integrity. However, only the Scottish scheme has conspicuous independence from those investigated. The Scottish Legal Services Ombudsman is publicly funded, and those investigated play no part in the appointment. She is accountable to the Scottish Parliament, formally presenting her annual report to it. Although the Lay Observer is publicly funded, his annual report is presented to the Council of the Law Society, as well as the Lord Chief Justice of Northern Ireland and the Department of Finance and Personnel. The Law Society does not play a part in the Lay Observer's appointment, but may be consulted by the Head of the Department of Finance about the scope and discharge of his functions. The Independent Adjudicator is appointed by, funded by and accountable to the Law Society of Ireland, and his annual report is presented to the President of the Law Society. This does not mean that he does not have operational independence, but it does present problems of 
perception. Problems of perception also afflict the Lay Observer, who has remarked that some members of the public do not believe that he is independent of the Law Society. The Scottish Legal Services Ombudsman does not appear to have these problems of perception. Recent research has not identified issues about independence, the main criticisms of the Ombudsman by complainants being focussed on the remit of the Ombudsman and operational matters (Customer Management Consultancy Ltd 2000; Scottish Legal Services Ombudsman 2000: 17-21; Scottish Consumer Council 1999).

\section{Effectiveness}

The effectiveness of the schemes depends upon a number of factors, including their accessibility to complainants. Accessibility relates to whether the process is easy for complainants to use. The two Irish schemes do not have formal procedures for dealing with consumer complaints. They receive so few of them that they are dealt with informally, and the practice seems to be to conciliate, as far as possible.

Complainants to the Scottish Legal Services Ombudsman have expressed some criticism of the quality of the ombudsman's explanations (Customer Management Consultancy Ltd 2000: 21, 23; Scottish Consumer Council 1999: 91). They also indicated a desire for personal contact with the Ombudsman, and there was some criticism of the time taken by the Ombudsman's process (Customer Management Consultancy Ltd 2000: 15). The present Ombudsman is not satisfied with the time taken by her office to process complaints. When she first took office, she was dealing 
with opinions that had arrived in the office 14 months earlier. She considered it embarrassing to criticise the Law Society for two or three months delay, when the Ombudsman had taken a year to process the complaint. She has now reduced the backlog and is turning around the cases within three months (Justice 1 Committee 2001: col. 2531). As the Law Society takes a week to send the file, the Ombudsman believes that her office ought to take no more than two further weeks to produce an opinion. Straightforward cases are now completed within three weeks of the letter of complaint. A target of 13 weeks is set for more complex cases, which allows time for an interview with the complainant, or for additional information to be provided, for example from the solicitor's file.

There is confusion among complainants about the Scottish Legal Services Ombudsman's role. In a recent survey of complainants to the Law Society of Scotland, only 27 per cent of respondents correctly identified the ombudsman's role, as that of examining complaints about the Law Society's handling of complaints against solicitors. One-fifth of respondents thought that the ombudsman could impose a decision on the Law Society, and, more worryingly, almost one-fifth seemed to have no idea at all what the ombudsman did (Scottish Consumer Council 1999: 65). Since that research, the ombudsman issued a new leaflet, which will hopefully clarify the role (Scottish Consumer Council 1999: 91). Clarification of the role will not however answer complainants' criticisms that the ombudsman cannot examine the merits of cases (Customer Management Consultancy Ltd 2000: 19, 31). In Northern Ireland, the Lay Observer believes that his title is confusing for complainants, and that it does not really give an indication of his role. He has recommended that that his title be reconsidered to make it more meaningful to the public (Lay Observer 1999: 8) and in 
order to highlight the independence of the office (Lay Observer 2000: 11). Consumer representatives in Northern Ireland also express concern that the public do not know what a Lay Observer is, or what he does, and that the name itself sounds weak [7]. In the Republic of Ireland, the Office of the Independent Adjudicator was widely publicised when it was established. There has been no research as to whether the public is knowledgeable about the role.

The question of effectiveness is also related to what the schemes are designed to achieve. One important factor about all three schemes is that they are not designed to give redress in relation to the substance of the complaint against the lawyer. The function of all schemes is the review of the way the complaint has been handled. The merits of the original complaint are not investigated, and there can be no substitution of the professional body's decision on this. The schemes do not exist as an appeal against the decisions of the professional bodies. The purpose of all the schemes is to ensure that the professional body has carried out the complaint-handling function fairly, thoroughly and impartially. As is the case for the Legal Services Ombudsman in England and Wales, this can be a source of confusion to complainants, who may have misconceptions about the role of these oversight bodies.

This is especially so in the case of the Scottish Legal Services Ombudsman, as consumers usually consider that an ombudsman's role is the redress of individual grievances. Despite the fact that the Ombudsman's literature makes the remit clear, many complainants have the expectation that the ombudsman can investigation the original complaint (Scottish Consumer Council 1999: 91). They take their case to the Ombudsman because they are unhappy with the outcome rather than the manner in 
which it was investigated by the professional body (Scottish Consumer Council 1999: 62-63). Complainants are critical because the Ombudsman cannot examine the merits of decisions, and many find it frustrating that provided the process is satisfactory nothing can be achieved by referring their case to the Ombudsman (Customer Management Consultancy Ltd 2000: 21). The Scottish Legal Services Ombudsman has admitted that complainants are frustrated because there can be no examination of the merits of cases. It is therefore no surprise that many complainants would like to see the Ombudsman's remit extended to allow her to consider the merits of cases, as well as handling (Customer Management Consultancy Ltd 2000:21). The previous Scottish Legal Services Ombudsman has noted that if complaints are to remain as part of the self-regulatory framework of the legal profession, "there requires to be an Ombudsman’s service with greater regulatory powers” (Scottish Legal Services Ombudsman 2000: 19).

The two schemes in Ireland are not "ombudsmen”. However, they do stand at the apex of the complaint-handling process for the two Law Societies. It is probably fair to assume therefore that those who are not satisfied with the decision from the Law Society will expect an investigation into the merits of the original complaint. The Lay Observer has noted that the main problem, when dealing with individual complainants, is "managing ... perceptions and expectations about the role and remit" (Lay Observer 2000; 17). There is therefore a problem of perception with these schemes, in that the public may believe that the role of the ombudsmen/adjudicators is to examine the merits of the case. The task, therefore, seems to be one of managing expectations, making it very clear to the public the limits and range of powers of the schemes. 
Despite the confusion and frustration of complainants, none of the post-holders is seeking increased powers to investigate the original complaint. Indeed, in England and Wales, where the Legal Services Ombudsman has this power, the number of investigations into the original complaint is very small. There, the Legal Services Ombudsman decided to take "a more robust approach to referring cases back to the professional body for reconsideration”. She has pursued “a deliberate strategy of demanding that the professional bodies handle complaints about their members properly, rather than examining individual complaints from scratch” (Legal Services Ombudsman 2000: 15). The present Scottish Legal Services Ombudsman had not been in post long enough at the time of this research to have formed an opinion about this. She did however note that the views of the Legal Services Ombudsman in England and Wales meant that there, the original complaint was only examined in rare cases. Certainly, any change in the powers to examine the merits of cases would require more resources for all of the schemes. For the Scottish scheme, it would require a larger office, with more caseworkers. For the two Irish schemes, such a change would be impossible under the present arrangements for their operation, as they have no office facilities or dedicated staff.

\section{Remedies}

In order to be effective, the schemes must have adequate remedies. It is clear from what has been said above, that the primary aim of all three schemes is not to investigate the original complaint of the consumer against the lawyer. The purpose of 
all the schemes is to ensure that the professional bodies deal with complaints effectively. In other words, these ombudsmen/adjudicator/lay observers are performing a review function. What powers do they have to ensure that their review is effective and achieves positive results for complainants?

In Scotland, the result of the investigation may reveal shortcomings in the professional body's handling of the complaint. If this is the case, the Scottish Legal Services Ombudsman can make a number of recommendations. She can recommend that the professional body provide the complainant with information and explanations about the underlying complaint and how it was dealt with. There can also be a recommendation that the professional body carries out a further investigation or that it reconsiders its conclusions. The Ombudsman can also recommend that the professional body exercise its statutory powers as regards the practitioner. This means, for example, that the Ombudsman can recommend that the Council of the Law Society should consider prosecuting the solicitor before the Scottish Solicitors Disciplinary Tribunal. The Ombudsman can also take a case to this tribunal, although this power has never been used. However, the present Ombudsman has identified a set of circumstances which might lead to a direct referral to the tribunal, for example, where the Ombudsman identifies strong grounds for professional misconduct and the Law Society refuses to investigate or re-investigate (Scottish Legal Services Ombudsman 2001: 26)

Since 1997, the Scottish Legal Services Ombudsman can recommend that the professional body pay compensation of up to $£ 1,000$, for the inconvenience and distress caused by a poorly handled investigation. In 1999, the Ombudsman made 
recommendations for sanctions in fifteen cases, ranging in amount from $£ 100$ to $£ 700$. The aggregate amount was $£ 3,950$, with the average recommendation being $£ 264$ (Scottish Legal Services Ombudsman 2000:8-9). In 2000-2001, the average amount of compensation recommended was $£ 350$; there were four cases where the maximum of $£ 1,000$ was recommended; and the total compensation recommended was $£ 11,475$ (Scottish Legal Services Ombudsman 2001: 23-26). The Ombudsman can also recommend that the professional body reimburse part or all of the cost of making the complaint to the Ombudsman. This latter power has only been used since the present Ombudsman took up her appointment, and is typically $£ 25$.

In the main, the professional bodies accept the Ombudsman's recommendations, and pay the award. In 1999, the Law Society paid a lesser amount in two cases (Scottish Legal Services Ombudsman 2000: 9). In 1998, one recommendation for compensation was not accepted (Scottish Legal Services Ombudsman 1999: 7). The previous Scottish Legal Services Ombudsman has also withdrawn (Scottish Legal Services Ombudsman 1999: 7) or reduced (Scottish Legal Services Ombudsman 2000: 9) compensation recommendations after accepting the professional body’s representations. The fact that awards are invariably paid may indicate a respect for the office of the ombudsman. It could however indicate that the ombudsman is making the award based on an assessment of what the professional body will accept, rather than on the needs of the case.

The professional body must respond to any recommendation within three months. If it is not willing to comply with any recommendation, the Ombudsman may publicise that failure together with any reason given for not complying, the costs of publicity 
being met by the professional body. In 1998, the Ombudsman used this power on two occasions, in relation to the Law Society. The cases were publicised in the Scotsman newspaper, and included the Law Society’s statement of reasons for not complying (Scottish Legal Services Ombudsman 1999: 7). The Ombudsman also made arrangements during 1998 to publicise the Faculty of Advocates' rejection of a recommendation to pay $£ 400$ to a complainant (Scottish Legal Services Ombudsman 1999: 31). The power was not used in the last year, although there was one case where it almost was (Scottish Legal Services Ombudsman 2001: 25-26). Neither the complainant nor practitioner may be identified in any publicity.

In Northern Ireland, the Lay Observer's remit is to ensure that the Law Society's processes are fair. He has no power to award compensation to complainants, even if he is critical of the Law Society's handling of the case. What he does do, is to try to achieve a satisfactory solution for the complainant, if possible. In the Irish Republic, the Independent Adjudicator can recommend to the Law Society that it reconsiders the complaint. He cannot make any awards of compensation. The two Irish schemes are not designed to provide compensation to individual complainants. Their aim in individual cases is to try to obtain a satisfactory result, either by recommending that the Law Societies reconsider the complaint, or provide a satisfactory explanation to the complainant. Only in Scotland, can there be compensation for the complainant, where the some fault is found with the way the professional body has dealt with the complaint. In none of the schemes is there any power to enforce the recommendations. 


\section{Effective oversight}

All the schemes have the function of ensuring that the self-regulatory schemes operated by the professional bodies are fair and effective. Given this emphasis, how effective are they in doing so? The Scottish scheme is the most wide-ranging of the three, in that it covers a range of legal professionals, extending the remit beyond solicitors, to advocates, conveyancers and executory practitioners. This follows the practice in England and Wales, where the Legal Services Ombudsman's remit extends to solicitors, barristers, legal executives, licensed conveyancers and patent agents. The two Irish schemes are limited to solicitors. There is a view that this does not present a problem, as it is the task of solicitors to ensure that barristers give good service. However, it does mean that the two schemes in Ireland do not provide independent oversight of the complaints procedures of the whole legal profession. The Lay Observer in Northern Ireland believes that this is an anomaly which should be addressed (Lay Observer 2001: 10).

In Scotland, information about the professional bodies' handling of complaints can only be obtained as a result of an individual complaint. In addition to providing a remedy for the individual, where appropriate, the Ombudsman can make general recommendations using the information gained from the cases investigated. These recommendations can be made to the professional bodies, and to the Scottish Parliament. They need not be confined to the complaint-handling functions of the professional bodies. They can also relate to other issues of good practice, which may have the effect of reducing the numbers of complaints. Recognising that most complaints are about communication problems, the previous Scottish Legal Services 
Ombudsman recommended on a number of occasions that the Law Society require solicitors to send letters of engagement to clients, containing information about the instructions and the basis of the charges. From 1994, he tried to persuade the Law Society that this would prevent misunderstandings. Finally, in 1999, the Law Society, although not making it a rule, agreed that the solicitors' Code of Conduct should be amended. Solicitors are now to provide information on fees, who will handle the transaction in the firm, and what the client should do if dissatisfied with the service (Scottish Legal Services Ombudsman 2000: 11).

In relation to complaint-handling, the Ombudsman did recommend that the Law Society provide the public with information about firms with serious and persistent record of inadequate professional service, but this was rejected. There have been successes. For example, there has been an increase in lay input into the complainthandling process. The Law Society has also broadly accepted the need for complaints about conduct to be investigated separately from complaints about inadequate professional services. Another eventual success was the recommendation that the Law Society establish a telephone helpline, so that people could access the Law Society easily for advice about how to make a complaint. The previous Ombudsman believed that the commitment of the Law Society to complaints-handling had improved over the years he had held office, but was very critical of the complaint handling process in the Faculty of Advocates. The major criticism here was the lack of lay involvement, and he tried, without success, to persuade the Faculty to establish a committee with two lay people as a minimum to deal with complaints. 
In Northern Ireland, the present Lay Observer has made a number of recommendations since taking up office in 1998. For example, he made suggestions for improvements in the Law Society's statistical review, which were accepted. He also made recommendations about the amount of lay participation, and as a result, the number of lay representatives on the Professional Conduct Committee has been increased from two to four. The Lay Observer notes that the Law Society's response to his recommendations has been "generally most positive and constructive” (Lay Observer 2000: 7). He has adopted a very proactive approach, seeing his role as collaborative and educational.

In the Irish Republic, the Independent Adjudicator made seven recommendations to the Law Society in his first Annual Report. These included the development of a practice management course, where solicitors could be directed to attend. The Independent Adjudicator also believes that the Law Society should encourage solicitors to confirm instructions and costs in writing. The validity of the recommendations was accepted by the Law Society, and the Independent Adjudicator believes that the recommendations he has made as a result of this overview have resulted in more investment by the Law Society in the complaints process. In addition, of the five amendments to the legislation affecting solicitors in 1998, two related to the Independent Adjudicator’s recommendations.

There can be no doubt therefore that these independent oversight schemes are a force for the good. However, their limitations must also be recognised. The chief advantage of the two schemes in Ireland is their power of audit. Unlike the Legal Services Ombudsman in England and Wales and the Scottish Legal Services Ombudsman, 
these two schemes include a power to access all the complaints files of the relevant Law Societies. Indeed, the focus of their work is in conducting an overview of the system in this way, rather than dealing with individual complaints. The Scottish Legal Services Ombudsman cannot conduct a general audit of the cases that are not referred to her. She can only investigate where there is a complaint from a member of the public. There is no power to make general inspections of files. This gives only a partial view of the system, and does depend upon complainants having the tenacity to pursue their grievances. A power to conduct an audit may ensure a more effective oversight function, providing a middle way between self-regulation, and an independent body to deal with complaints. The previous Scottish Legal Services Ombudsman has recommended that the powers of the ombudsman be extended to enable an annual audit of cases determined by the professional bodies where there has been no complaint to the ombudsman.

\section{Conclusion}

The legal profession, like other professions, has traditionally enjoyed the privilege of self-regulation, within a statutory framework. However, in recent years, selfregulation has come increasingly under attack, and questions have been raised about the appropriate regulatory mechanisms for professions in general and client complaints in particular. These questions occur when the professions are failing to inspire public confidence. One solution to this problem is for the professional bodies to improve their procedures and increase client satisfaction. Consumers expect high standards of service, and if their expectations are not met, they will complain and 
expect redress. They are no longer prepared to defer to the professionals and if professional bodies fail to deliver consumer satisfaction, governments have shown themselves prepared to impose schemes to protect the consumer interest.

Complaints procedures represent only a small part of regulation and self-regulation. They are however those aspects of regulation which directly affect consumers. Confidence in these systems can inspire confidence in the regulatory system as a whole. Conversely, if the redress system fails to inspire public confidence, it calls into question the whole regulatory system. Joint regulation is one method of achieving public confidence in the system and client satisfaction with legal services. The selfregulatory stage of the process is less costly, more flexible and more amenable to change than statutory regulation would be. It can be more effective because it avoids the implementation problems associated with coercive mechanisms of control. Because there will always be public scepticism with self-regulation, oversight of the self-regulatory mechanisms by an independent body is necessary.

The schemes presented in this paper represent two types of joint-regulation. The two Irish schemes have very clear auditing functions, with wide ranging powers of inspection. They can obtain a full picture of the operation of the systems. Their drawback is the lack of power to award compensation where the professional bodies have failed to deliver effective complaint handling. Nor can they compel the professional bodies to follow their recommendations. In addition, they are partial systems, having oversight only over solicitors. Barristers and other legal professionals are not included in their remit. The Scottish system, which is more akin to the one in England and Wales, can provide compensation, but it is dependent on individual 
complaints in order to access the professional bodies' systems. It lacks the power to conduct a complete audit of the system, nor does it have powers of compulsion. The two Irish schemes do seem to be more internally coherent, but they are limited to the solicitors branch of the profession.

The problem with all the schemes is the limitation on their remit. All are confined to an investigation of process rather than merit. If this is accepted as an appropriate role, a major task is that of addressing public expectations in this regard. The public must also be convinced that the oversight body has the power to effect change to the first tier process, and thus be persuaded that this is an appropriate role. Unless this can be achieved there will be no confidence in this joint public and private, self-regulatory and statutory, system, and pressure for a completely independent redress mechanism becomes hard to resist. 
Notes

[1] An earlier version of this paper was presented to the Joint Meeting of the Law and Society Association and Research Committee on Sociology of Law, held in Budapest, Hungary, on 4-7 July 2001.

[2] There has been a comparative study of solicitors' complaints procedures in England, Wales, Scotland and Northern Ireland (see Ross and Enoch 1996).

[3] The research was carried out over a twelve-month period, from January 2000. It comprised interviews with the Scottish Legal Services Ombudsman (previous and present); the Lay Observer in Northern Ireland; and the Independent Adjudicator of the Law Society in the Irish Republic. There were also interviews with staff in the client relations sections of the Law Societies in the three countries, and consumer organisations in Scotland and Northern Ireland. Information was also gathered from published sources, in particular the annual reports of the bodies concerned. The author would like to record her most grateful thanks to those who agreed to be interviewed, for their openness and co-operation. This project was made possible by funds from the Research Enhancement Fund, Nottingham Trent University, which support is much appreciated.

[4] The British and Irish Ombudsman Association was set up in 1993, originally as the United Kingdom Ombudsman Association (the name change in 1994 followed the inclusion of three ombudsman schemes from the Irish Republic as members). It was formed on a self-regulatory basis, as a result of concern that the title "ombudsman" was being used inappropriately. The Legal Services Ombudsman and the Scottish 
Legal Services Ombudsman are full voting members of the British and Irish Ombudsman Association. The Lay Observer has associate status.

[5] The Office of Law Reform deals with civil law and policy that does not fall within the province of other departments. In effect, it deals with all legal matters except crime, employment and social services. Regulation of the legal profession is within its remit.

[6] His first annual report took as the theme “client satisfaction” (Lay Observer 1999), his second one "self-regulation and client care" (Lay Observer 2000). His most recent annual report focuses on complainant management (Lay Observer 2001).

[7] Personal interview at the General Consumer Council for Northern Ireland.

[8] This kind of power would also strengthen the oversight function of the Legal Services Ombudsman in England and Wales. The case for this was argued in R.James and M. Seneviratne (1995: 206). The Legal Services Ombudsman in England and Wales has not called for this power. Such a power would have huge resource implications for her office. 


\section{References}

Barnes, M. (1994) Monitoring and Evaluating Methods of Regulation. In

Proceedings from the Annual Research Conference 1994: Profession, business or trade: Do the professions have a future? )The Law Society's Research and Policy Planning Unit). Law Society: London.

Customer Management Consultancy Ltd (1998) Satisfaction in a super-escalated complaint environment. A report to the Office of the Legal Services Ombudsman. Lord Chancellor's Department: London.

Customer Management Consultancy Ltd (2000) Survey of Complainers to the Scottish Legal Services Ombudsman. Scottish Executive Central Research Unit.

Independent Adjudicator of the Law Society (1999) Independent Adjudicator of the Law Society: Second Annual Report to The President of the Law Society of Ireland 1998/1999.

James, R. and Seneviratne, M. (1995) The Legal Services Ombudsman: Form versus Function? Modern Law Review 58(2), 187-207.

Justice 1 Committee (2001) Evidence from the Scottish Legal Services Ombudsman

to the Justice 1 Committee of the Scottish Parliament, Official Report $21^{\text {st }}$ Meeting 2001, Session 1, Tuesday 5 June 2001.

Lay Observer (1998) Twentieth Annual Report of the Lay Observer 1996/97. The Stationery Office: Belfast.

Lay Observer (1999) Client Satisfaction = Client Perception - Client Expectation:

$21^{\text {st }}$ Annual Report of the Lay Observer 1997-98. The Stationery Office: Belfast. 
Lay Observer (2000) Self-regulation and Client Care: $22^{\text {nd }}$ Annual Report of the Lay Observer 1998-99. The Stationery Office: Belfast.

Lay Observer (2001) Complainant management "Levelling the Playing Field": $23^{\text {rd }}$ Annual Report of the Lay Observer 1999-2000. The Stationery Office: Belfast. Legal Services Ombudsman (2000) Demanding Progress: Annual Report of the Legal Services Ombudsman 1999/2000, HC 583. The Stationery Office: London. Legal Services Ombudsman (2001) Reflecting Progress: Annual Report of the Legal Services Ombudsman 2000/2001, HC 30. The Stationery Office: London.

Ross, M. L and Enoch, Y.T. (1996) Complaints against Solicitors: A Comparative Study of the Solicitors' Complaints Procedures in Scotland, England and Wales, and Northern Ireland. Scottish Law and Practice Quarterly 1, 145-158 (Part I:

Procedures); 216-223 (Part II: Procedures and Practice); 331-339 (Part III:

Comparison and Comment).

Scottish Consumer Council (1999) Complaints about Solicitors: a Study of Consumers' Experiences of the Law Society of Scotland's Complaints Procedure. Scottish Legal Services Ombudsman (1999) Scottish Legal Services Ombudsman Annual Report 1998. The Stationery Office: Edinburgh.

Scottish Legal Services Ombudsman (2000) Scottish Legal Services Ombudsman Annual Report 1999, SE/2000/57. The Stationery Office: Edinburgh.

Scottish Legal Services Ombudsman (2001) Scottish Legal Services Ombudsman Annual Report 2000-2001, SE/2001/123. The Stationery Office: Edinburgh. Seneviratne, M. (2000) Consumer complaints and the legal profession: making selfregulation work? International Journal of the Legal Professions 7(1), 39-58. 